\title{
Perceptions. The Unbuilt Synagogue in Buda through Controversial Architectural Tenders (1912-1914)
}

\author{
Éva Lovra
}

Akcija "Pravo na prvu šansu" - Province of Vojvodina, Provincial Secretariat for Higher Education and Scientific Research, 2400 Subotica, Serbia; lovra.eva@eng.unideb.hu

Received: 12 September 2019; Accepted: 5 November 2019; Published: 8 November 2019

\begin{abstract}
The unbuilt synagogue in Buda is an almost forgotten chapter in Hungarian architectural history which drew great attention between 1911 and 1914. It was discussed extensively by the contemporary press in the early 20th century and by architects in the Hungarian capital of Austria-Hungary. Between 1912 and 1914 three tenders for the design of the synagogue of Buda were announced, with the participation of well-known (synagogue) architects of Hungary, who represented the diverse architectural styles of the period. The efforts to build the synagogue, including the three failed tenders, the 30 competition designs and the opinions of contemporaries raised, and continue to raise, many provocative questions. The present study is based on the analysis of the designs submitted and criticisms published in official architecture magazines between 1912 and 1914, but not yet studied and published elsewhere. Through these, the study showcases the controversial architectural decisions that could have changed the appearance of a neighbourhood but failed to do so. The study puts the townscape of Széll Kálmán Square in Buda in a new context, revealing another layer of architecture, urban design and architectural-sociology and perception of the capital's synagogue on the eve of World War I and the dissolution of the Austro-Hungarian Empire.
\end{abstract}

Keywords: architectural competition; Austria-Hungary; Buda synagogue architecture; perception

\section{Introduction}

The largest synagogue in Buda would have towered over Széll Kálmán Square, and dominated the view of the Buda side of the Hungarian capital, Budapest.

The author's personal interest in the history of the Postal Palace ${ }^{1}$ (architect: Gyula Sándy, ${ }^{2}$ built 1924-1926), the Eclectic-Art Nouveau building that nowadays defines the square at the foot of the Buda Castle hill, pointed to an almost forgotten chapter in Hungarian architectural history which gained great attention between 1911 and 1914. The Postal Palace was built on a vacant lot that had been planned for non-secular functions in the early 20th century, namely for the greatest synagogue on the Buda side of the capital of Hungary. The planning process and the controversial competitions were discussed extensively by the contemporary press in the early 20th century and by architects in the capital. Today, however, only a small portion of the planning history of the synagogue of Buda is known, primarily due to the integrity of one of the applicants, namely, Béla Lajta ${ }^{3}$ (Lajta Archive

1 The Eclectic-Art Nouveau building became a focus of interest in 2018 when it was bought by the National Bank of Hungary and its renovation and conversion was launched.

2 Gyula Sándy (Prešov, 1868-Budapest, 1953), architect and university lecturer. In addition to renovating monuments, he designed buildings including numerous Lutheran churches in Budapest and Pest county (e.g., the Reformed Church in Nagykőrös), schools and community institutions, like the postal palaces in Budapest and Zagreb.

3 Béla Lajta (Leitersdorfer until 1907) (Óbuda, 1873-Vienna, 1920), architect. His early works were greatly influenced by Ödön Lechner. After 1905 he moved away from the characteristic Lechner style. The buildings, designed after 1909, are identified 
2010). The architect participated in the first round of the competition in 1912, but remained silent in the following two (1913 and 1914). His reputation as the leading architect of the time, the result of his role in the pioneering architectural movement, makes it even more interesting that this chapter of Hungarian architectural history has been almost forgotten: almost, since we are aware of how it started; however, the big finale is still cloaked in shadow.

The current study will reconstruct the complex, and in many cases controversial and paradoxical tale of the urban and architectural competition, with greater emphasis on the second (1913) and third (1914) tenders and the social context. The greatest synagogue architects of the time played only a supporting role in this storyline, but their aesthetic principles affected the synagogue competition submissions.

The prologue of the desire to build a great synagogue on the Buda side is rooted in a 19th-century development. By the end of the 19th century, the Jewish community of Buda had three smaller temples, and it was not until the end of that century that the growth of the community reached the point where it was necessary to build a great synagogue.

Jews began to settle in Buda in 1783 (again ${ }^{4}$. The Pest Jewish Community became independent from the Óbuda Jewish Community by 1793, and became the largest and richest Jewish community in Europe by the end of the 19th century. It was only towards the end of the 19th century that the development of the Jewish community in Buda gained momentum. At that time, as a result of the establishment of the Rose Hill (Rózsadomb), the Margaret (Margit) Boulevard and the Lágymányos, districts, the population increased from just a few hundred members, to 7000, and their institutions could not keep up with this rapid growth. The shortcoming of the available institutions may have raised the idea of a new great synagogue, and unification with the Pest Jewish Community in the 1920s, but the autonomy of the community remained until the 1950s.

Between 1912 and 1914, three tenders for the design of the synagogue of Buda were announced, with the participation of well-known synagogue-designer architects of the Austro-Hungarian Empire, representing the diverse architectural styles of the period. Among them were the above mentioned Béla Lajta, whose first prize-winning design of 1912 foreshadowed Art Deco, as well as the modernism of the 1920s, and the design team of Marcell Komor and Dezső Jakab, ${ }^{5}$ whose design was linked to Ödön Lechne's ${ }^{6}$ national secessionist aspirations. The partial success of the first competition for the Buda Synagogue in 1912 was followed by another tender in 1913, where only invited participants were asked to submit a proposal for the last round in 1914. However, after the announcement of the final results, news stopped for a while regarding the urban block of the Buda synagogue, including the site between Krisztina Boulevard, Csaba Street, Vérmező Street and Várfok Street in District I of Bud.

by simple, geometrical and monumental forms, but never gave up the use of ornamentation-most of their ornamental motifs of folk art emphasize structural or functional elements. His work can be divided into four eras: Floral Art Nouveau, Arts and Crafts, Art Deco, Geometric Art Nouveau or Early Modern. He created significant buildings in each of these eras.

4 On 17 June 1746, Maria Theresa banned all Jews from Buda, September 8 was the deadline for emigration. The city still collected the tax for 1746, and the Jews left the city before the deadline. Some of the exiles settled in Old Buda, others scattered throughout the country and the rest migrated to Poland (Újvári 1929, p. 146). In 1783 Joseph II. proclaimed the "Systematica gentis judaicae regulatio", the law of free movement, which nevertheless restrcited Jews from settling in mining towns (Újvári 1929, p. 212).

5 Architect Marcell Komor (Pest, 1868-Deutschkreutz, 1944) and architect Dezső Jakab (Vadu Crisului, 1864-Budapest, 1932) are two great figures of the national Art Nouveau movement (Hungarian Sezession) initiated by Ödön Lechner. They started working together in 1897 and opened their office in 1899. Their cooperation lasted until 1918. Their urban planning assignments included the creation of a new city centre in Târgu Mures, and the Palace of Culture which was one of the most conceptual creations of the era. Additionally, several public buildings were designed for Subotica (Synagogue, 1902; City Hall, 1908-1910; Bank, 1907; savings bank, 1908; buildings in Palić, 1909-1912), as well as the Erkel Theater (1912-1913) and Palace Hotel (1910-1911) in Budapest; city hall and a music palace (1906) in Bratislava (etc.).

6 Ödön Lechner (Pest, 1845-Budapest, 1914) was the father of the Hungarian Secession movement (Hungary's brand of art nouveau). He aimed to create a distinct National Style blending art nouveau with Hungarian folk motifs and Oriental elements. As a creator of the independent Hungarian style of architectural identity, he had many followers, including Béla Lajta, Lipot Baumhorn, Dezső Jakab and Marcell Komor. Lechner's most famous buildings are the Museum of Applied Arts (1896), the Geologiacal Institute Building (1899) and the Hungarian State Treasury (1901) in Budapest. 
In the final competition of 1914, the plans of Sándor (Samu) Löffler and Béla Löffler ${ }^{7}$ were chosen as the winning entry. However, in the end their plan was not implemented, and another competition to design the building was envisaged, which was prevented by the historical circumstances.

The First World War set back the development of the Jewish community of Buda. The fact that there was no problem in the leadership of the community can only be attributed to the then-president, Izidor Szabolc. From 1922, the election of Károly Baracs as court counsellor marked the beginning of a new era for the community. His main merit was in consolidating the financial position of the community. The community's plan back in 1912 to build a new great temple was again put on the agenda: "This plan [referring to the plan from 1912] was blocked by World War I, but community leaders have kept it on the agenda ever since. Thus, in 1929, with the headquarters, the construction of the great temple will begin" (Újvári 1929, p. 149).

The Jewish community of Buda had lost its financial security between 1914 and 1922, and its dreams of a great synagogue had to be postponed as well. The official report of 1923 states that "a large block of land which has been lying abandoned and in bare fallow for many years is going to be built on via state-regulated public construction appropriately to its exclusive location" (FKT 1928, p. 96). According to the Municipal Council of Public Works' official report issued in 1928, named as the construction of the "Buda telephone centre", the land was acquired by the capital in 1923 by appropriation, obtained through an exchange with the Jewish community of Buda. Along with the plot, the capital of 100,000 crowns was given to build a new synagogue, headquarters and a park.

The financial boom which began in 1922 provided the basis for the construction of the new synagogue, but no longer on the same site, but in today's Széll Kálmán square, and not in the spirit of the results of the 1910s tenders. The efforts to build the synagogue, including the three unrealised tenders, the thirty competition designs and the opinions of contemporaries raise many provocative questions. The unbuilt synagogue could be placed within the category of synagogue architecture and universal architecture of the Austro-Hungarian Empire (then Central Europe, 1867-1918) via the analyses of the designs, competition documents and the urban context. In the course of the debate following the tenders the sociography that emerged reflected the professional environment of the time, and the characteristic aspects, of which the most noticeable are the urban architecture strata.

The study is based on the analysis of the designs and criticisms published in official architectural magazines between 1912 and 1914, but not yet studied and published elsewhere. Through these, the study showcases the controversial architecture decisions that could have changed the appearance of a neighbourhood, but failed to do so. The three-year period was defined by architectural and social debates, accusations and decisions which partially transformed other state tenders, after those of the Buda synagogue. One of the greatest scandals of the time was not just the three following unsuccessful tenders and the humiliation of the participating architects, who submitted 30 designs overall, but the fact that the Buda Jewish community hired Franz Roeckle ${ }^{8}$ together with the selected architects in 1914. The German architect, designer of the Great Synagogue in Frankfurt, served as a member of the jury during the first competitions. The question was inevitably raised as to whether he was the main reason the previous two competitions had failed. Marcell Komor stated "that an architect of such a

7 Béla Löffler (Budapest, 1880-?) and Sándor Löffler (Samu) (Budapest, 1877-?), architect brothers that worked at the turn of the century and during the Early Modernist period. In 1906 they opened an independent office. Several tenement buildings in Budapest were designed following the principles and detailed practice of the Lajta Office (Magda Court, 1911-1912; Burger house, 1908). Their most significant work is the Kazinczy Street Synagogue (1912), along with the school and the community building. Between 1897 and 1899 Béla worked in the office of Frigyes Spiegel, and later at Béla Lajta's. His design that was submitted to an international competition for the synagogue in Antwerp in 1923 was successful. In 1925, his design won the competition for the National Theater in Jerusalem. He later had a design office in Alexandria. Sándor was primarily responsible for management and office administration during the time of their cooperation. After the war, he independently designed apartment buildings in Budapest.

8 Franz Roeckle (1879-1953), a Lichteinstein-based architect who won the competition for the design of the Westend synagogue. In 1932, he joined the National Socialist German Workers' Party, however, in 1924 he was in charge of the building of the Institute of Social Research. 
calibre as the one from Frankfurt there must be probably at least two dozen among Hungarians ( ... )$^{\prime \prime 9}$ Nevertheless, this was just one episode of controversy during the three-year period, which was interrupted by World War I and the downturn of the finances. The study will analyse and evaluate the web of the events and decisions, and puts the townscape of Széll Kálmán Square in Buda into a new context, revealing another layer of architecture, urban design and architectural-sociology and perception of the capital's synagogue on the eve of World War I, the dissolution of the Austro-Hungarian Empire in 1918, and the disintegration of Hungary in 1920. In addition, the background behind the contests and the opinions of contemporaries reveal a diverse evaluation and aesthetic perception of synagogue buildings. However, they were primarily a subjective judgment and not a condition of Jewish liturgy.

The period from 1918 was neither economically nor politically favourable to the Jews of Hungary, or the construction of a new synagogue. However, the two plans for the Buda synagogue should be analysed from an architectural point of view. In their monumentality and architectural purity, the plans of Béla Lajta (1912) and the Löffler brothers (1914) could have been valuable pieces of Central European architectural history.

\section{Results}

\subsection{Background of the Buda Synagogue Architectural Tender-Aims and Perspectives}

Austria-Hungary was formed by the Austro Hungarian Compromise (1867, Ausgleich), initiating the progressive development of Hungary. Following the Compromise, one of the foremost among the liberal reforms was the XVII. Law on the Equalization of Israelites in Civil and Political Rights in 1867 (1867: XVII. t.c. Az izraeliták egyenjogúsításáról polgári és politikai jogok tekintetében). When the law was enacted, the Jewish population became equal to the Christian population with respect to all civil and political rights. The same law superseded all other laws and decrees. The neolog Jewish religion was born as a unique phenomenon in the world. However, the religious equalization of the Jews was not fully completed until 1895, when, under the prime ministerial office of Sándor Wekerle, the XLII. Law on the Israelite Religion (1895: XLII t.c. Az izraelita vallásról) came into force. From then on, Judaism became one of the accepted religious denominations of the Hungarian nation.

As a result of the emancipation act of 1867, Jewish immigration from neighbouring countries without similar laws began to increase. More and more Jews declared themselves to be of Hungarian nationality. By the end of the 19th century, Hungary had evolved in an unprecedented way, catching up with some of its Western European neighbours by the early 20th century, and even overtaking them in certain areas. Civic development until the end of World War I also helped to assimilate and strengthen Judaism. A large group of intellectuals, entrepreneurs and traders was established, who reconciled their Hungarian nationality with their Jewishness. The newly launched metropolitan development, the inclusive attitude of the majority, and the official policy of creating a modern nation-state through the mass merger of nationalities also provided opportunities for the Jews to enjoy equal social status and belonging within the Hungarian nation.

In Buda, the establishment of the Rose Hill (Rózsadomb), the Margaret (Margit) Boulevard and the Lágymányos districts enhanced the growth of the community and the number of the Jews rose from just a few hundred to 7000 . The institutional background could not keep up with this rapid development.

The history of the construction of the Buda synagogue begins in 1907. In this year, the council of Budapest allocated 100,000 crowns for the construction of the synagogue, and from 1908 this sum was transferred to the Jewish community in three instalments. ${ }^{10}$ In 1911 the Municipal Council of

9 Ezrey [Komor, Marcell]: “Zsidó templom Budán." Vállalkozók Lapja, 7 January 1914, p. x.

10 Pesti Napló, 27 September 1907, p. 13. 
Public Works ${ }^{11}$ agreed on a location and the Council granted an area of 1462 orgia quadrata ${ }^{12}$ (about $5260 \mathrm{~m} 2$ ) for the construction of a new synagogue, headquarters and park on Krisztina Boulevard. In exchange for this the community conceded two of its properties which had been the synagogue and servant apartments in use at 5-7 Öntőház Street. According to the FKT official report (FKT 1928, p. 96), the community rented the Öntôház Street building back and used it as a prayer house until 1923 as it could not complete the construction of the new permanent synagogue on Krisztina Boulevard until then. In 1923 the entire urban block bordered by Krisztina Boulevard, Csaba Street, Vérmező Street and Várfok Street was selected for the construction of the Buda telephone centre (Postal Palace, 1924-1926). Two plots of this urban block where the Buda Synagogue would have been built were obtained by expropriation. After the expropriation of these plots the plot at Öntôház Street and the rented synagogue were returned to the Jewish community in Buda.

Due to town planning considerations an agreement was made as the building construction was a state-financed development. In a prestigious area of the town which had been abandoned and unexploited for many years, a monumental public building appeared. Finally, it was incorporated in an 'appropriate way' by 1926. 'Appropriate way' meant designing a building of architectural and urban value, irrespective of its function and character, as was indicated by the initial agreement made between the Jewish community in Buda and the Municipal Council of Public Works.

In line with the original concept, the design of the synagogue, headquarters and park was the subject of an invitation-only to a competition issued by the Buda Jewish community in 1912, the terms of which were published in the Bulletin of the Community. ${ }^{13}$ Among the invited architects were many well-known and recognized synagogue architects from the territory of Habsburg Hungary. Among the selected architects was Lipót Baumhor ${ }^{14}$ who designed and renovated 25 synagogues in Austria-Hungary from the 1880 s until his death. Another was Béla Lajta (Leitersdorfer), ${ }^{15}$ who presented new solutions in each of his designs since the secessionist movement. His works anticipated Art Deco in 1910, and Modernism in the 1920s, and were at the forefront of European architecture of the era, as they represented a consistently high standard of work in the Art Nouveau ${ }^{16}$ style.

Additionally, the architectural duo of Gyula Haas and Béla Málnai, designers of modern Hungarian architecture, were selected to participate. Furthermore, Richard Schöntheil, who designed the former Kőbánya synagogue (1909-1911); Marcell Komor and Dezső Jakab, the designers of the Subotica synagogue (1901-1902); József Vágó and László Vágó, outstanding figures of the Hungarian Art Nouveau movement; and Vilmos Quittner, designer of the Gresham Palace (1905-1907) in Budapest, were also members of the group of architects selected for the synagogue competition. The following architects also participated in the tender: Medgyes (Messinger) Alajos, Manó Pollák, Ede Földes and Miklós Schreiber, Imre and Dávid Gondos, Zsigmond Jónás, Béla Lossányi, Vilmos Magyar, and Nándor Dévai.

11 In the citation referred to as FKT, according to the original name, Fővárosi Közmunkák Tanácsa in Hungarian.

12 Historical unit for measure — quadratklafter (Ger.), orgia quadrata (Lat.)

“Tervpályázat új fótemplomunk építésére." A Budai Izraelita Hitközség Értesitője, 1912, pp. 13-16.

14 Lipót Baumhorn (Kisbér, 1860-Kisbér, 1932), architect. He is undoubtedly the most renown individual in Hungarian synagogue architecture. His most creative decades of work involved the design and construction of synagogues, however his work was not limited to the design of synagogues. His designs for savings banks, schools, residential buildings and palaces are also of great importance. In his buildings, the signs and aspirations of the late Eclectic and Art Nouveau styles can be observed at the same time.

15 The architect was only involved in the first competition, thus we are aware of the 1912 contest.

16 The denominations of Art Nouveau came from the Secession, the modern art group in Vienna to Habsburg Central Europe (szecesszió in Hungarian), although the artists (and people in general) attempted to withstand the influence of Vienna, as the fear of cultural Germanization was present (Kann 1977, pp. 552-53). The regional impact in general and in art and architecture (due to Otto Wagner, Joseph Maria Olbrich and Adolf Loos) was significant, further because Vienna has been recognised as a centre of Art Nouveau besides Brussels, Barcelona, Munich and Paris since the start. In the fin-de-siècle art history, both the local versions and the general phenomenon in the Habsburg Central Europe are apt to interpretation in the context of the achievements of Viennese architects (Moravánszky 1998, p. 151). 
The entries to the architectural design competition were judged by representatives of the leading architectural associations of the era. The Hungarian Architects' Association and the Hungarian Association of Engineers and Architects, and a foreign architect, along with representatives of the Jewish community in Buda were included. The names of the contestants were secured by pseudonyms and the identity of the jury members was revealed only when the decision was announced and not before. The chairman of the jury was Dr. Izidor Szabolcsi, the president of the Jewish community. The other members were the Hungarian architects Flóris Korb, Emil Mattauschek, and Manó Pollák from Budapest. In addition, Franz Roeckle, a foreign architect and designer of the Great Synagogue in Frankfurt, was on the jury. This last one was intended by the Jewish community to play a greater role later.

Let us return to the primary conditions that remained the same throughout the 1912, 1913 and 1914 competitions. The task, as stated in the announcement, was "to satisfy the modern and artistic needs ( ... ), maximize the spatial impact on the religionists (.. ), be impeccably bright, centrally heated and ventilated $(. .$.$) the sanctuary could be seen from every place without exception and impediment."17$ The total cost of the church, the town hall and the environment which would accommodate at least 1400 people should not exceed 800,000 crowns. However, the total budget was eventually increased to over 1 million crowns to cover each of the award-winning entries on which the jury commented in 1912. Manó Pollák ${ }^{18}$, Julian Wagner ${ }^{19}$ and the Komor-Jakab architect duo produced the background study that led to launching the architectural competition. One of the most complex tasks for the architects who entered the competition was not to satisfy the general building conditions, but to design the building in accordance with the topographic conditions (various heights). In addition to a proper background study, the success of the competition was "guaranteed by the individuality of those called by virtue of their talents have excelled in designing our temple."20

\subsection{Architectural Competition in 1912: The Controversial Decision}

On 22 June 1912 the results of the architectural competition were announced, to which the magazines and the press paid much attention. The submissions to the design competition were open for public viewing for two weeks, to both professional and non-professional audiences. The periodicals reported the results. Some designs were published and discussed in professional papers like the Teropályázatok, the Épitó Ipar and Der Architekt in 1912. The representative nature of the synagogue planned for one of the most prestige locations on the Buda side, at the corner of Krisztina Boulevard and Vérmezô Street, and the amount of investment attracted much attention. However, the controversial decision by the jury provoked the greatest interest and a negative fervour. According to the jury: "None of the submitted plans goes beyond the requirements of this task, either generally or individually. In particular, no plan addressed the issues of utilizing significant terrain differences, carriageways and organ placement. For this reason, no plan is mature enough to serve as a basis for drafting the working-drawings. The prizes, however, will be awarded in terms of their artistic and technical merit." 21

Béla Lajta's work received the first prize, and Imre Gondos ${ }^{22}$ was awarded the second. The third prize went to Sándor Löffler and Béla Löffler, who did not appear as invited architects in the official

\footnotetext{
“Tervpályázat új főtemplomunk építésére.” A Budai Izraelita Hitközség Értesítoje, 1912, p. 14.

Manó Pollák (Sučany, 1854-Budapest, 1937): architect. He designed buildings in the Art Nouveau style.

Julian Wagner (?-?), Austrian origin master builder.

“Tervpályázat új főtemplomunk építésére." A Budai Izraelita Hitközség Értesitóje, 1912, p. 16.

"A budai izraelita templom tervpályázata." Tervpályázatok. Magyar Építómúvészet, 1912, p. 17.

Izidor (Imre) Scheer, from 1907 Gondos (1860-Eger, 1930), architect and master builder. In 1892 he opened his office, designed tenement houses, business centres and a factory. He took part in important architectural competitions: in 1898 with László Vágó and József Vágó in the competition of the Synagogue in Lipótváros, and in 1928 he was one of the few Hungarian architects to take part in the international competition for the Palace of Nations (Geneva).
} 
call. The plans of Dávid Jónás ${ }^{23}$ and Zsigmond Jónás ${ }^{24}$ were purchased. Among the bought plans were the designs of the architects Ármin Leindörfer (Leimdörfer) ${ }^{25}$ and Rácz (first name is unknown), who were also not among the architects invited to the competition. Finally, Manó Pollák participated in the work of the jury as a lecturer and not as a competitor. Before a deep analysis of the various designs, it is important to take a brief look at how contemporaries commented on the award-winning work. Vilmos Magyar, ${ }^{26}$ an aspiring architect at the time, writes the following about Béla Lajta's plan in his article in the Épitó Ipar: "It is a top-notch artistic work in every taste, built this way. It would be the best and the most truthful Jewish temple on the continent. (... ) The façade is monumental in its captivating simplicity. It's full of mystery. The forms of ancient Sasanian and Phoenician memories come alive that prove to be the predestined forms of the Jewish temple under the guidance of its designer" ${ }^{\prime 27}$. However, Lajta's plan did not fully comply with the competition brief. Due to the terrain, the synagogue is positioned perpendicular to Krisztina Boulevard; therefore, it is oriented in the northeast direction instead of the east, and the building is adjacent to the boulevard. Géza Lengyel (pseudonym: -et.), the correspondent of the Pesti Napló, stated that "The formal solution is serious and serene. Lajta designs an oriental style building ensemble, that does not reflect the conventional Spanish-Moorish synagogue-style overloaded with arabesques but large, smooth wall surfaces, domes with extraordinary, perhaps exaggerated and risky simplicity. ( . . . ) It seems to be very thoughtful and even its first sketch represents excellent absorption, but in our opinion, he does not take enough account of the character of the place. In the narrow and hilly Buda this dignified, widespread construction is as contradictory as, for example, the pointed Gothic Parliament building on the wide Danube bank."28

The existence and location of the Hungarian Parliament building (Imre Steindl, 1885, completed in 1904) on the Pest side has gained legitimacy over the years (Figure 1), but it is difficult to imagine that Lajta's plan could fit in with the cityscape and the changes in the built environment from the perspective of a 100 years.

Arthur Elek (pseudonym: e. a.): "The round, flat dome rises above the square of the temple. The tender protocol describes this architecture as »being abstract «. According to our view it is perfectly right because you really feel that it is not in its future material that its designer imagined it, but rather on the paper." ${ }^{29}$ According to Rudolf Klein's analysis: "The plan of the Buda Synagogue proves that it was prescient for Lajta to see the correspondence between modernism and the Judaic tradition: the rejection of ornamentation (pagan sacrifice), the abstraction (inconceivable God), the white and contentless walls (the primacy/freedom of ideas in the visually delimited concrete representations), the importance of the time factor (life as a time-warping phenomenon waiting for the Messiah), and the space-time of modern architecture, derived from Maimonides' philosophy and Jewish mysticism through Einstein and Minkowski's theories." (Klein 2013, p. 43)

Contemporaries commented on Imre Gondos' second prize plan (Figure 2): "But the layout of the temple is beautiful. It is so economical that it can be built from the appropriation, which is a merit. The temple area is covered by a huge dome with a great space effect. Among the award-winning designs, this has the most beautiful interior effect." ( ... ) "Undoubtedly the jury liked the large, round,

23 Dávid Jónás (Pest, 1871-Budapest, 1951), architect. He worked in Atelier Felmer and Helmer, then returned to Budapest in 1900. For a long time he worked with his brother Zsigmond Jónás building villas and apartment houses, and later became the architect of the Hungarian State Railways.

24 Zsigmond Jónás (Budapest, 1879-Budapest, 1936), architect. In 1906 he was awarded the gold medal of the Hungarian Society of Engineers and Architects. For a long time he worked with his brother Dávid Jónás. Their jointly designed buildings includde the Szénássy and Bárczay department stores, the Palace of Tolnai's World Journal, and the Goldberger warehouse.

25 Ármin Leindörfer (Leimdörfer) (?-?), architect from Budapest.

26 Vilmos Magyar (?-?), architect and architectural writer.

27 Magyar, Vilmos. “A budai zsinagóga pályázata.” Építo Ipar, 14 July 1912, p. 272.

28 Lengyel, Géza (pseudonym: -et.). “A budai új zsidótemplom. Tervkiállítás a MÉSZ-ben." Pesti Napló, 4 July 1912, p. 13.

29 Elek, Artúr (pseudonym: e. a.). “a budai új zsinagóga pályatervei." Az Ujsag, 4 July 1912. 
uniform interior space of the church first and it is truly impressive. However, the committee itself recognizes its architecture as » being conventional and dry «. In any case this is the slightest judgment that can be said of it."30 " ( . . ) only the circular floor plan, which extends into a square, deserves this distinction, and its artistic training is by no means." 31

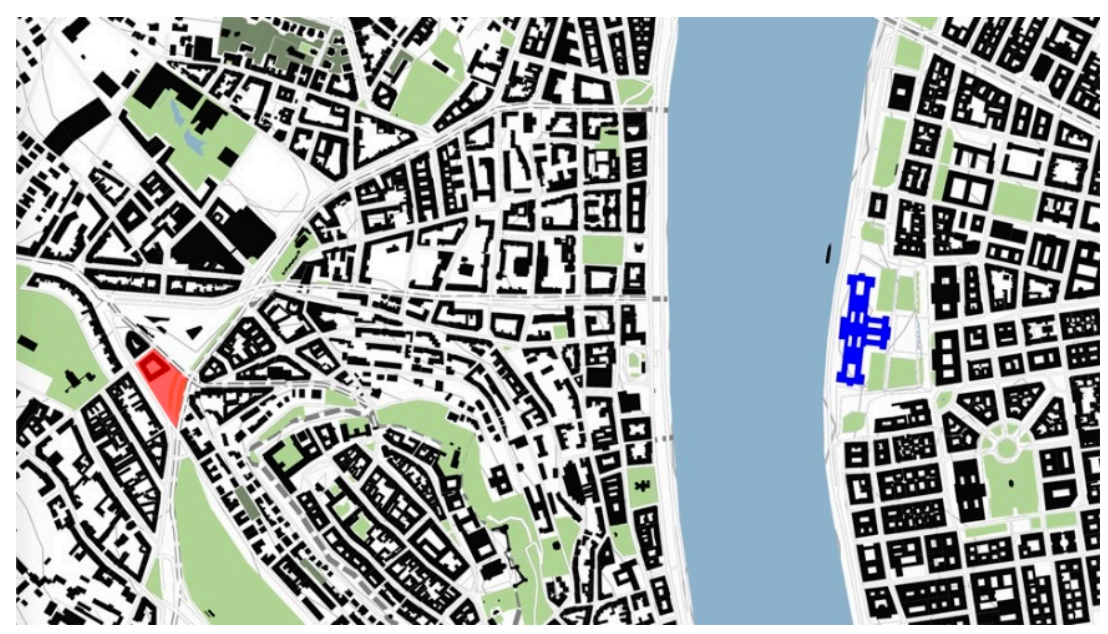

Figure 1. Urban context and the position of the Buda synagogue (red: the site of the synagogue, blue: Hungarian Parliament building). Source: swarzplan.eu and own editing.

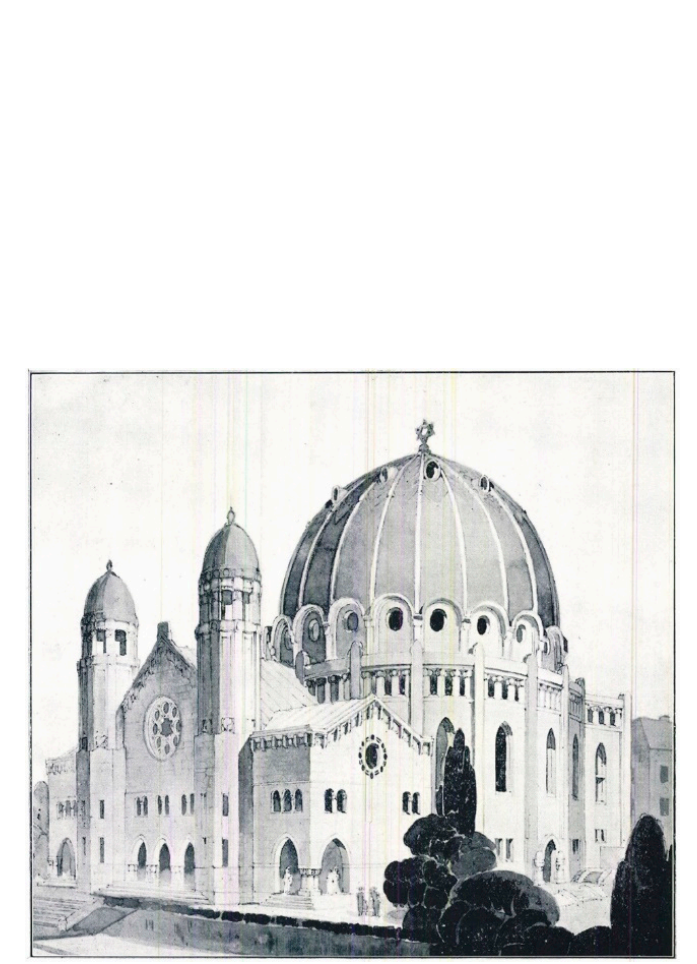

(a)

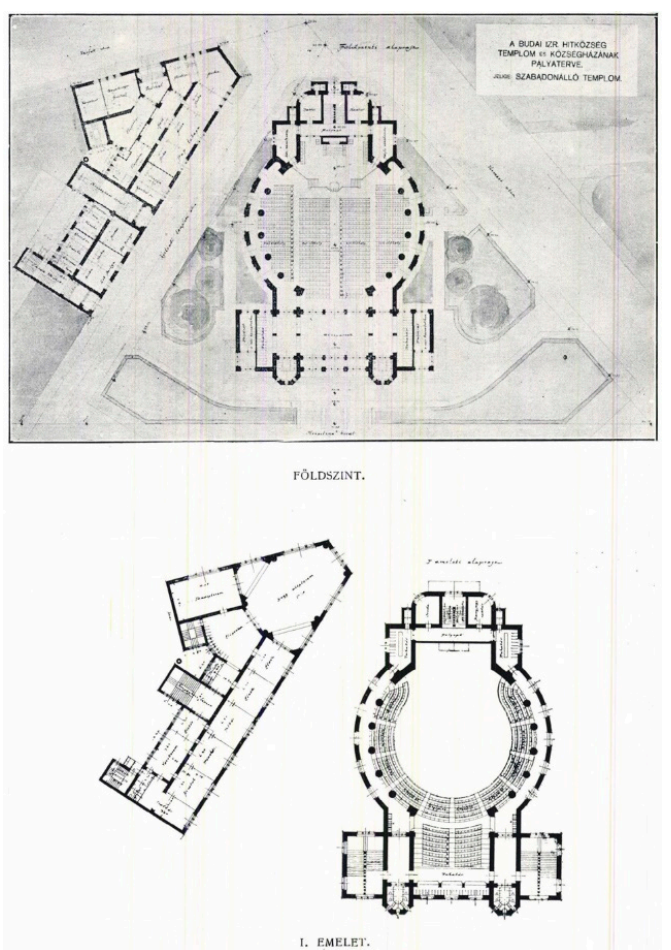

(b)

Figure 2. (a) Perspective view of Imre Gondos' 2nd prize design (Imre Gondos, 1912). Source: Magyar Épitőmüvészet 1912, p. 18. (b) Floor plan of the synagogue building (Imre Gondos, 1912). Source: Magyar Épitőmüvészet 1912, p. 20.

\footnotetext{
30 Lengyel, Géza (pseudonym: -et.). “A budai új zsidótemplom. Tervkiállítás a MÉSZ-ben.” Pesti Napló, 4 July 1912, p. 13.

31 Elek, Artúr (pseudonym: e. a.). “a budai új zsinagóga pályatervei.” Az Ujsag, 4 July 1912.
} 
The work of the Löffler brothers strictly complied to the requirements with the synagogue sanctuary facing east (Figure 3). This solution was only possible to the detriment of space. "They keep the eastern axis precisely. This enables them to construct a small triangular space in front of Krisztina Boulevard and a nice park from the south. The solution of the temple itself was less successful but the design of the space around the temple seems to be better. The park in front of the temple and the small triangle cut in front of the boulevard are incorporated in the architecture of the temple in an artistic and picturesque way." 32 "According to its floor plan this design is similar to the structure of a basilica whose centre is crowned by the dome which rests on the eight-sided drum. The style of the building is the traditional eastern synagogue style with many tiny ornaments. Although it presents right proportions and tasteful arrangement." 33 Apart from the architectonic solution, the placement of the temple is innovative and one of the most appropriate designs. The large differences in terrain height were resolved by placing the temple on a horizontal plateau level above Krisztina Boulevard but below Várfok Street. As a result of this solution, the church is visually submerged from Várfok Street.

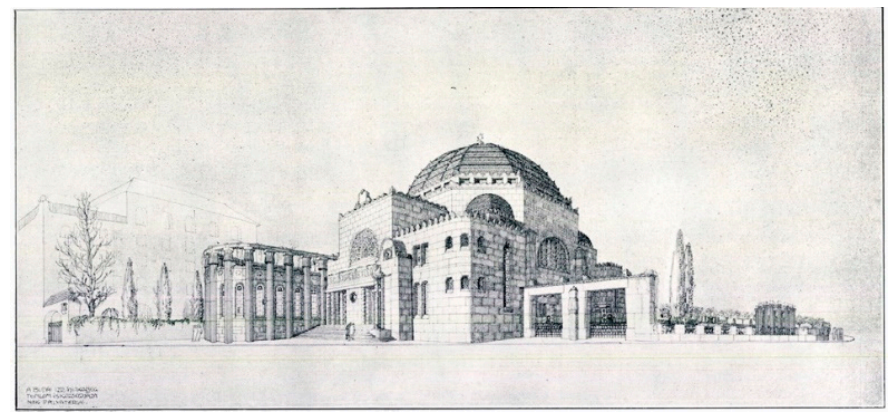

(a)

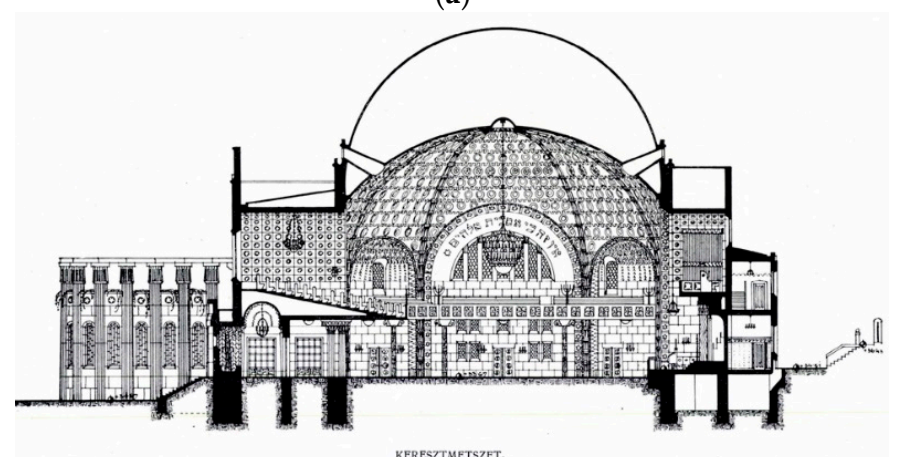

(c)
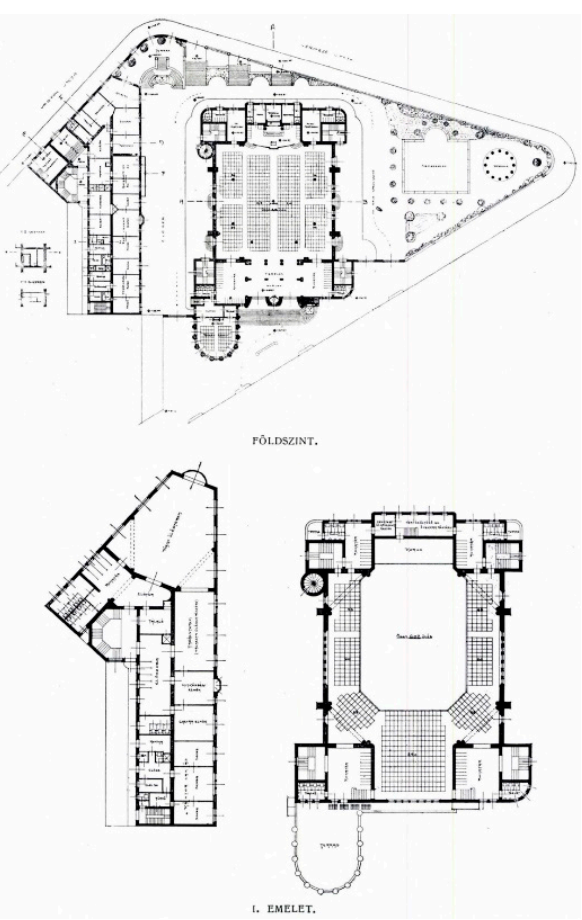

(b)

Figure 3. (a) Perspective view of Sándor and Béla Löfflers 3rd prize design (Sándor and Béla Löffler, 1912). Source: Magyar Épitömüvészet 1912, p. 21. (b) Floor plan of the Buda synagogue (Sándor and Béla Löffler, 1912). Source: Magyar Épitőmüvészet 1912, p. 25. (c) Cross-section (Sándor and Béla Löffler, 1912). Source: Magyar Épitőmüvészet 1912, p. 23.

The Löffler brothers' work, examined in light of the massing of the proto-Modern Kazincy Street synagogue that they designed, points out that their architectural-aesthetic conception was subordinated to the Jewish traditions and brought out the maximum from the design area. They managed to design an orthodox synagogue and a façade design which was appropriate to the narrowness of Kazinczy Street.

Apart from the top three designs, the identity of other designers who participated in the competition was not disclosed in the press. The contemporary press did however draw attention to work named as "Hungarian Jewish Church". Responding to the triangular site, the designers of this plan chose

32 Magyar, Vilmos. “A budai zsinagóga pályázata." Építo Ipar, 14 July 1912, p. 272.

33 Elek, Artúr (pseudonym: e. a.). “a budai új zsinagóga pályatervei." Az Ujsag, 4 July 1912. 
a triangular building layout. The authors of the plan were, in fact, Marcell Komor and Dezső Jakab (Figure 4). In their design they also applied the decorative accessories of the Hungarian Art Nouveau movement (Hungarian Secession), such as they did in the case of the Szeged synagogue competition. Their design was eventually built in Subotica after minimal changes. This type of architectonic language and form were the elements of their design that the jury of the 1912 competition disliked. Such an "architecture that seeks to be Hungarian, thus a national character" (as Vilmos Magyar stated), was labelled as "unusual" by the members of the jury. Hungarian Secession, however, was not so unusual a style in Hungary during that time, as the synagogue had been built in Subotica only about ten years before the Buda competition. In terms of space, the Subotica synagogue, as we can quote Rudolf Klein, slightly exceeds the achievements of its contemporaries. with respect the history of the style, it is a pioneering building, as it is the first Hungarian-Art Nouveau synagogue in the country (Klein 2017, p. 509).

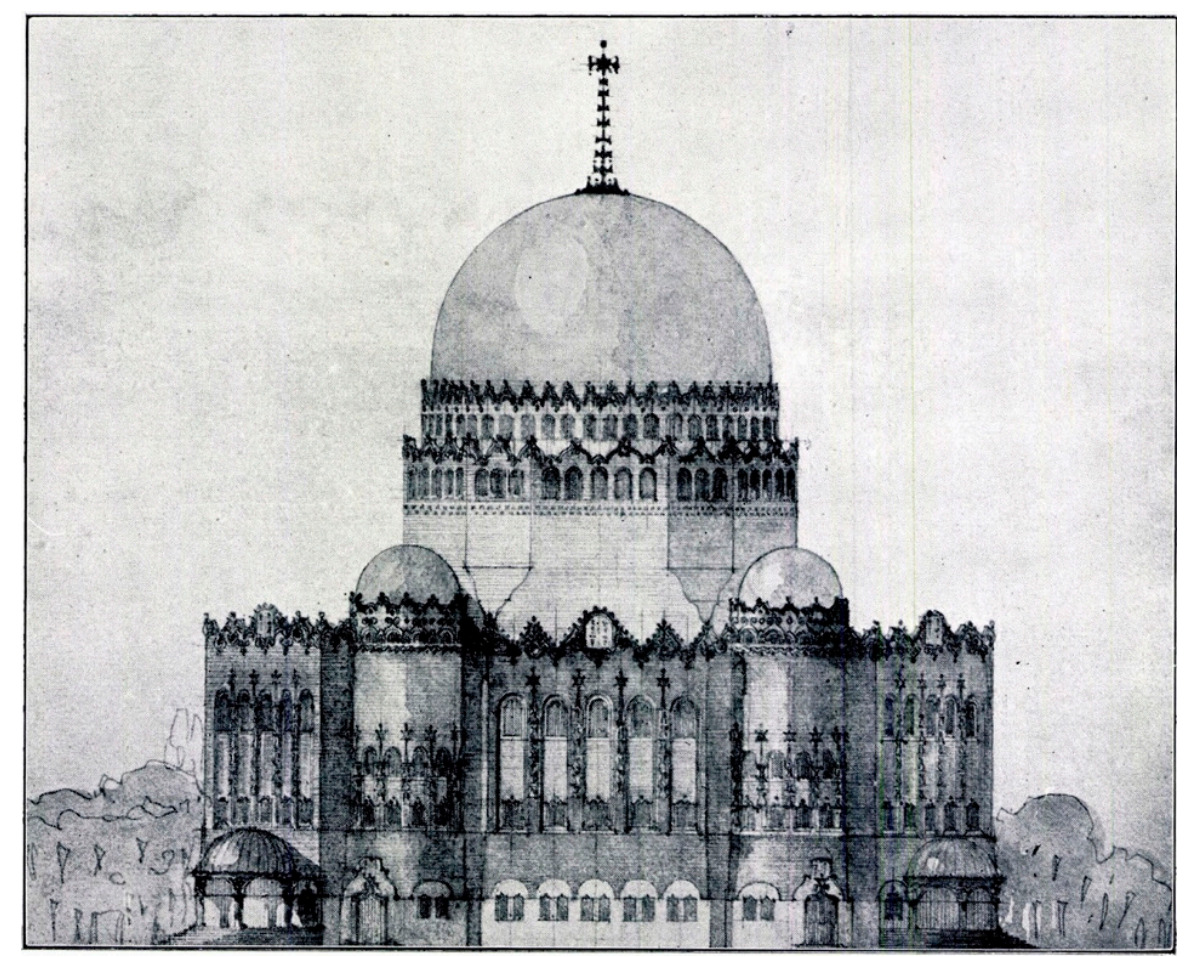

Figure 4. Hungarian Art Nouveau (Hungarian Secession) design for the Buda synagogue (Marcell Komor and Dezső Jakab, 1912). Source: Magyar Épitőmüvészet 1912, p. 23.

According to Klein's synagogue typology, it can be said that the Byzantine temple-type synagogues (Gondos, Löffler, Komor and Jakab) dominate among the published designs. Imre Gondos also designed a Westwerk-like precinct with a foyer (more like a Catholic church type) surrounded by two towers on both sides. The plans of David Jónás and Zsigmond can be called hall-type with a bit of compromise, but based on the ground plan it is a catholic church, as there seems to be a longhouse, a Westwerk, as well as an apse. The perspective view depicts a hall-like structure.

Among the ten plans submitted to the invitational competition, the jury did not find any suitable for implementation. Therefore, the community announced a new, but this time, public tender in 1913.

Apart from the authors of the ten plans submitted to the competition, and the authors of the six published plans, some significant names were missing. The question may be what happened to Lipót Baumhorn's plan? Did he even make it at all? Or did Baumhorn remain on safe grounds (flatland) with the design types that allowed for minimal variation? 


\subsection{Architectural Competition in 1913: Rumors}

The primary expectation of the second, this time public, architectural competition was that Hungarian architects apply en masse: "Because of the beautiful location of the land in question, it is capable of accommodating a monumental building and the community is not sparing any sacrifices to raise a beautiful temple worthy of the capital. It is hoped that the architects participating in the competition will be as numerous as possible." ${ }^{34}$ The architects were allowed to prepare their applications for four and a half months. Finally, on 2 June 25 the plans were submitted.

After judging the competition entries, the jury found that none of the architectural designs had met the required "standard" (the same term was also used concerning the first competition). Although no prizes were awarded among the designs, there seemed to be several "works with more valuable thoughts and relative artistic estimation which were not recommended for purchase by the jury, simply because paragraph 24 of the ministerial regulation ${ }^{35}$ contains a prohibition on it [does not allow them to buy any of the plans, if the competition failed]." ${ }^{\prime 36}$ Despite the ban, the community recommended the purchase of four plans (pseudonyms: Szombat, Messiás, Alef, Üdvöske). ${ }^{37}$ The authors of these plans were published as Imre Gondos, Sándor and Béla Löffler, Vilmos Magyar and Hugó Gomperz. However, plan no. 4 was ascribed to Gomperz in the published article by mistake, while the real identity of the designer was József Porgesz. ${ }^{38}$

The failure of the two competitions for the Buda synagogue sparked speculation, and gave rise to several accusations. There seemed to be problems with the application of the Löffler brothers. As an unidentified complainant claimed, under the pseudonym of "One Architect from the Capital", Dr. Izidor Szabolcs, the president of the Jewish community promoted the work of the Löffler brothers because they were close relatives of one of his key clients, Lipót Beck and his son. Szabolcs rejected this accusation. ${ }^{39}$

The disputed plan of the Löffler brothers from 1913 (pseudonym: Messiás) was the first in the presentation that had been revised from the 1912 design. The new concept solved the temple space, which was disputed in the previous plan, by covering it with an octagonal and regularly shaped dome. Imre Gondos (pseudonym: Szombat), however, not only revised the details of his plan but completely redesigned it. In the first submission the synagogue was a completely free-standing building, while the second plan put the synagogue in close contact with the head-quarters of the community and attached the two buildings. Analysing the synagogue-type of the previous plan, the elevated façade had been transformed, although it preserved the Romanesque façade facing Krisztina Boulevard. Vilmos Magyar (Üdvöske), who analysed and commented on the works of the previous competition in 1912, also wrote about some of the entries of the 1913 competition in the pages of Épitó Ipar. He described Gondos' plan as follows; "The temple space is a square covered with a dome with slight projections on each side and with column halls on three sides. Its façade achieves monumental simplicity and an oriental character." 40

The fourth purchased plan was József Porgesz's (Alef) work. In his design, the façade of the synagogue is calm and monumental (Figure 5). He also took advantage of the significant differences in the levels of the site in the massing of the synagogue. The differences in topography made possible to design a basement under the hall, which was placed in front of the temple. Thus, it allowed men and

\footnotetext{
Budapesti Hirlap, 18 January 1913, p. 17.

Fövárosi Közlöny, 12 August 1910, p. 1435.

Budapesti Hirlap, 2 July 1913, p. 14.

Az Ujság, 18 July 1913, p. 15

8 József Porgesz (Öcsöd, 1880-1944, in a concentration camp in Germany), architect. Together with Sándor Skutetzky won the Kazincy Street Synagogue architectural tender. Although their work was the best among the competitors, the Pest Autonomous Orthodox Jewish Community chose to build the design of the Löffler brothers.

39 Pesti Napló, 27 July 1913 and 29 July 1913, p. 15.

40 Magyar, Vilmos: “A budai zsidó templom második tervpályázata." Épitő Ipar, 3 August 1913, p. 339.
} 
carriages to enter the synagogue from the courtyard, while women could reach the gallery stairway from Krisztina Boulevard.

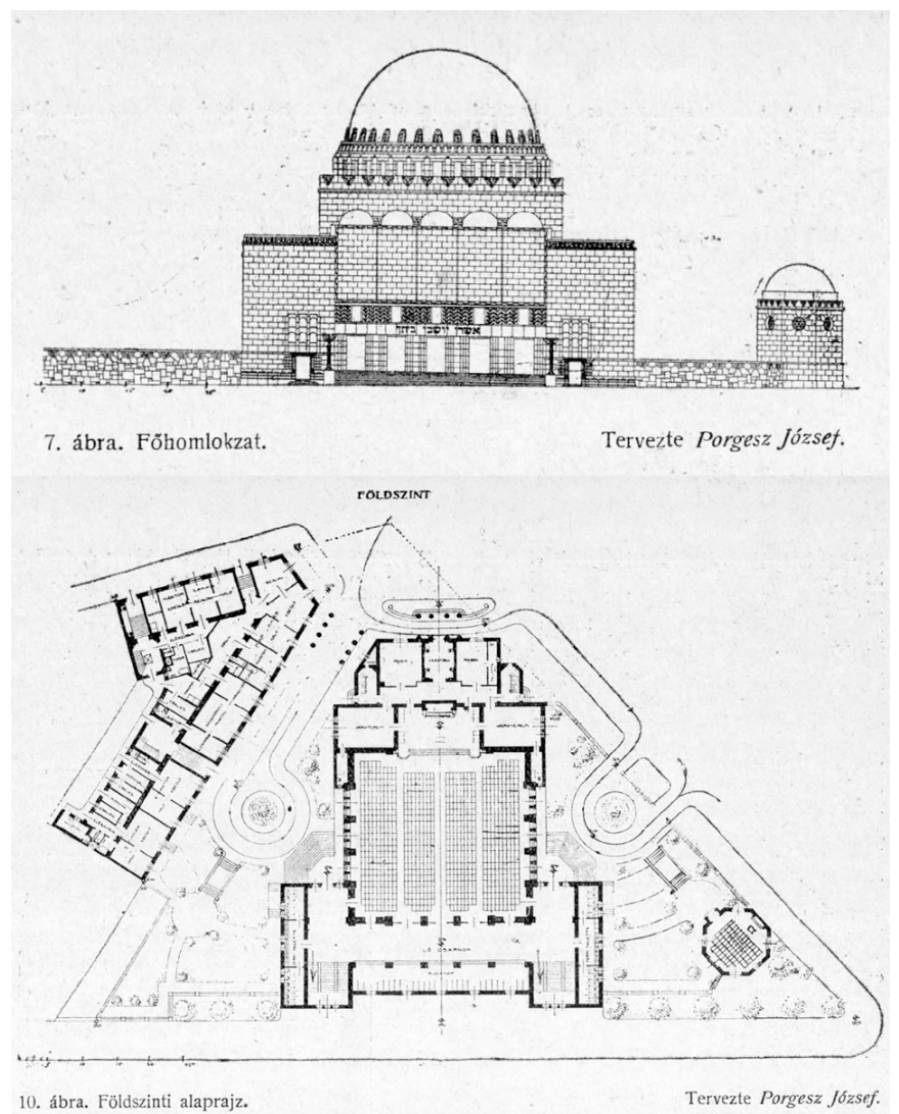

Figure 5. Main façade and plan of the ground floor of the Buda synagogue from the design of József Porgesz submitted to the 1913 architectural competition. Source: Épitő Ipar, 27 July 1913, p. 328.

As in the first competition, the jury was inconsistent in their approach. They did not adhere to the criteria set out in the call for proposals, and even overrode them in some cases. Thus, a distance of $10 \mathrm{~m}$ should have been left between the synagogue and the headquarters of the community, a condition that was stipulated by the Municipal Council of Public Works, but the jury commended a plan (Figure 6) that attached the two buildings (the plan of Imre Gondos).

Vilmos Magyar felt so strongly that this was a factor in the two unsuccessful tenders that it triggered a minor scandal at the end of 1913, finally peaking in the first half of 1914, before the third competition call was announced.

\subsection{Architectural Competition in 1914: The Second Scandal}

In December 1914, the construction commission announced that it would hold another limited competition for the design and construction of the synagogue. There were several possible directions available to the community, however, according to the new brief for the architectural competition "the community announces a new public and national tender, precisely the third based on a new program that has been properly established. Or, the [community] calls on those who have made the best plans in the current competition for a narrower tender. In this case, the community can even include in this narrower tender the architect whom they would like to entrust directly to the design." 41

41 Magyar, Vilmos: “A budai zsidó templom második tervpályázata.” Épitő Ipar, 15 July 1913, p. 330. 


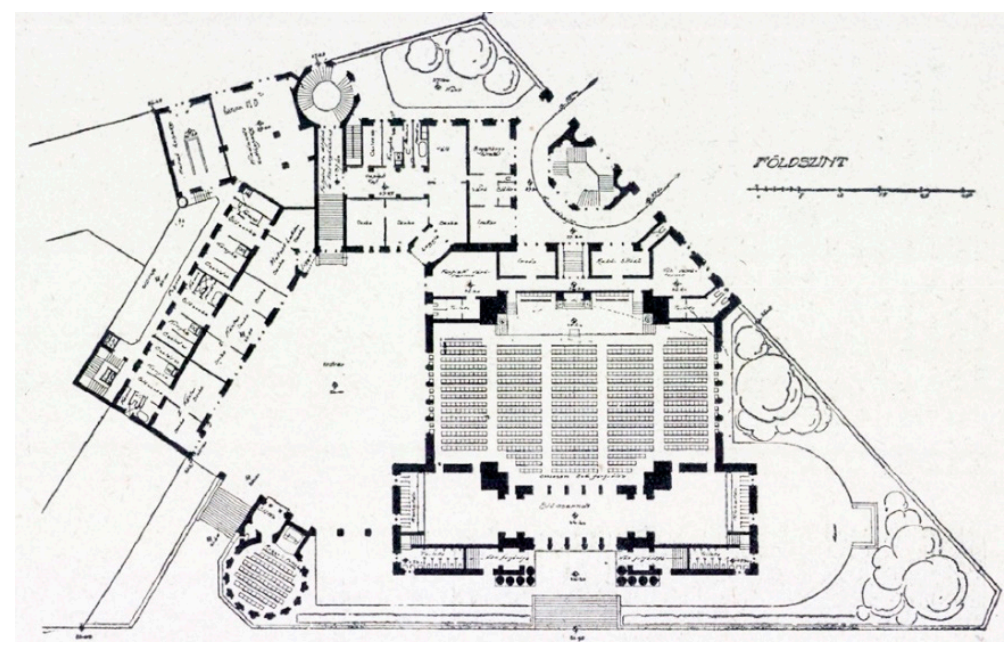

Figure 6. Floor plan, the attached buildings of the synagogue and the headquarters of the community (Imre Gondos, 1913). Source: Épitő Ipar, 20 July 1913, p. 318.

In addition to award-winning architects, the Jewish community invited a German architect to be a participant, as he was also involved in the first and second competitions as a member of the jury. The origins of Franz Roeckle, the architect of Frankfurt's great synagogue, were used as an excuse and held against him. The question seemed to be raised as to whether he himself was the main reason that the previous two competitions had failed.

At a general meeting, where the matter of the failure of the previous competitions, and the involvement of a foreign architect were on the agenda, István Bárczy, the mayor of Budapest, was asked for his opinion by the representatives of the leading architectural associations in Hungary. Mayor Bárczy declared that "he doesn't know about it, but he'll be interested in it, and if they really want a foreign architect to do the job, the capital cannot grant any aid." ${ }^{42}$ As in 1907, the capital had voted to give a 100,000 crown grant to the Jewish community in Buda to build a synagogue. The grant was only one-tenth of the actual costs, but demonstrated the efforts required for ratification.

On 3 January 1914, the Pesti Napló formally advised that the Jewish community had commissioned the architect Franz Roeckle to build the synagogue in Buda. First, the Hungarian Association of Architects, then the Hungarian Association of Engineers and Architects made moves to prevent this from being realized. The two organizations turned to the capital to object to expending the aid, and to not to including Hungarian architects in the design of the synagogue. On January 3, a delegation from the Hungarian Association of Engineers and Architects visited Dr. István Bárczy, mayor of Budapest, escorted by Pál Balla, senior technical adviser for trade. The mayor was asked to prevent the Buda Jewish community, which had received a grant of 100,000 crowns from the capital and a building plot from the Public Works Council, to have a foreign architect design and build their temple. ${ }^{43}$ Mayor István Bárczy advised the delegation that the council could not legally intervene with the community, because the council had not made it a condition that only a Hungarian architect could design the synagogue. According to Bárczy, even though the capital did not make such a stipulation,"During the next council meeting they will deal with the case, and will advise the community to change its decision. The mayor also stated that in the future it would always be stated specifically that building with aid granted by the city should only be done by a Hungarian architect." 44

In a statement, Izidor Szabolcsi, the president of the Jewish community in Buda, summarized why they had made this decision. "None of [the plans accepted for the invitational competition in

42 Pesti Napló, 18 December 1913, p. 19.

43 “A megsértett magyar építómúvészet." Világ, 3 January 1914, p. 12.

44 Pesti Napló, 3 January 1914, p. 17. 
1912] were such a work that may have served as a basis for construction. Therefore, our community has invited the three awarded authors to participate in a competition which is not so extensive [probably a competition among themselves, although there seems to be no written record about this very competition if Szabolcsi's explanation is not referring to the new competition of 1914], then on 5 January 1913 a new public tender was launched and our most famous architects were invited to participate in the competition. Twenty-five submissions were received, but there were no absolute [complete and excellent] plans among them. So a total of thirty-three architectural designs have been submitted, and our community was still unscheduled and unable to start work. At that time, we applied for the invitation of a foreign architect who had designed the Jewish temple in Frankfurt. Therefore our community is beyond reproach." 45

In January 1914, Marcell Komor [Ezrey] explained in a lengthy article what the opportunity to design the Buda synagogue had meant to the architectural society. As he wrote, he was not surprised "that there had been such architects who had wanted to design this temple for free, without any honorarium." However, "I can whistle [writes Komor] that an architect of such a calibre as the one from Frankfurt, there must be probably at least two dozen among Hungarians $(\ldots)^{\prime \prime 46}$

\subsection{Architectural Competition in 1914: The Fundamental Idea}

In spite of fears and declarations, on January 26, 1914, four Hungarian architects submitted their proposals for the design and construction of the Buda synagogue. After the unsuccessful first and second competitions, the Jewish community invited the four Hungarian architects who had submitted the four best designs in the second competition, namely Imre Gondos, Sándor Löffler and Béla Löffler, Vilmos Magyar and József Porgesz. Franz Roeckle, the architect of the Frankfurt synagogue, was invited to participate as designer. He declined the opportunity and did not participate in this competition as previously he had served as a jury member for the previous competitions.

The failure of the previous competitions was partly due to the challenges of the site, such as the large differences in the topography, and the irregular shape of the site. Moreover, the brief had stated that the triangular plot on Krisztina Boulevard was for the synagogue only. Furthermore, it was stipulated, a separate plot area was to be provided for the building of the official community premises and flats. This might have been the main reasons for the failure. Therefore, these conditions were eliminated in the newest design competition. The competition entries also proved that due to the shape and location of the plot, orientating the temple to the eastern was impossible. Therefore, this condition was dropped as well. The jury for the 1914 competition included Antal Hoffhauser and Antal Palóczy (Palóczi), architect-teachers; Edmund Körner, architect-teacher in Darmstadt, who had designed the Essen synagogue; Manó Pollák, architect; Jenő Kiss E., engineering contractor and technical adviser to the Jewish community and to Izidor Szabolcs, president of the community. In addition, Samu Grünwald, president of the Chevra, Ignác Keller, and Bertalan Löbl, members of the prefecture, were also included. ${ }^{47}$ The jury reached a unanimous verdict.

According to their judgment, none of the plans was appropriate to be constructed in the form as submitted by the applicants. However, the jury found the "fundamental idea" of one plan suitable for implementation. This so-called fundamental idea was delivered by the joint design of Sándor Löffler and Béla Löffler (Figure 7), enabling the construction of Buda synagogue. ${ }^{48}$ Taking into account the building site, the new requirements of the competition brief, and the buildings to be built, it can be said that only such a design could provide an optimal layout and arrangement of buildings which takes advantage of the side of the site facing Krisztina Boulevard. All four plans attempted to take advantage of this opportunity, however, only the Löffler brothers created a plan in which the building massing

45 Budapesti Hírlap, 16 January 1914, p. 15.

46 Ezrey [Komor, Marcell]: "Zsidó templom Budán." Vállalkozók Lapja, 7 January 1914, p. x.

47 Világ, 14 March 1914, p. 12.

48 Budapesti Hirlap, 14 March 1914, p. 17. Pesti Napló, 14 March 1914, p. 18. Magyarország, 15 March 1914, p. 18. 
correctly reflects the locational conditions. This was a solution, based on such building massing and arrangement, which was mentioned by the jury as the correct "fundamental idea".

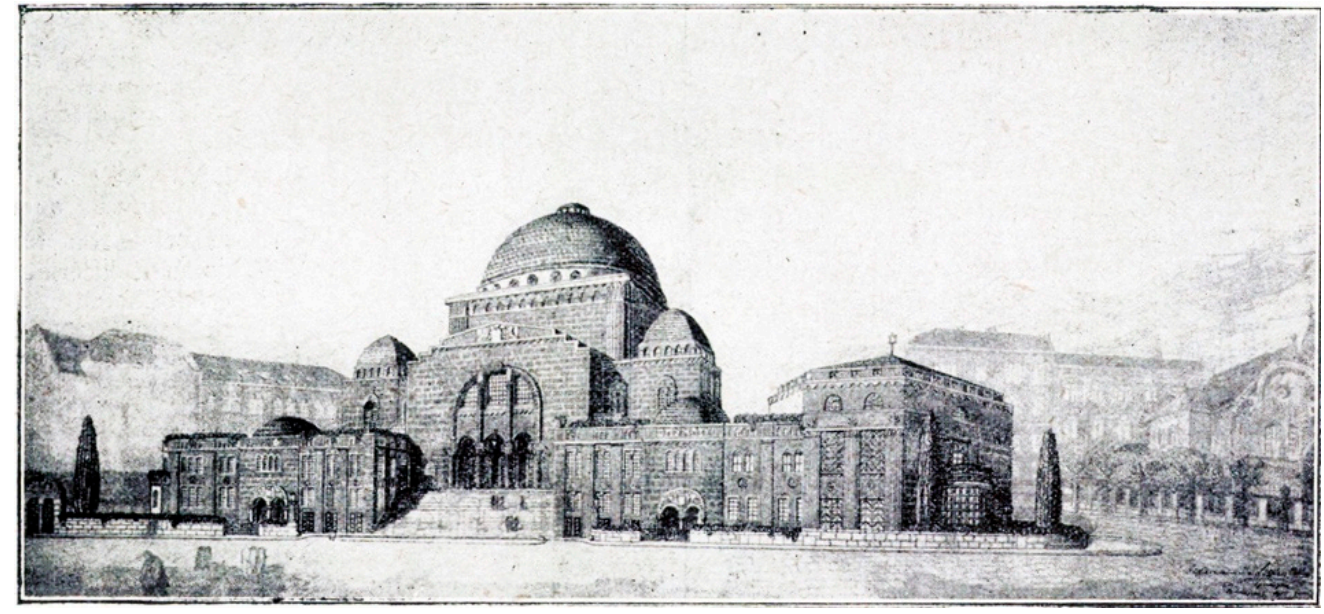

Figure 7. Perspective view-mass division and building arrangement as the "fundamental idea" (Sándor and Béla Löffler, 1914). Source: Épitő Ipar-Épitő Müvészet, 22 March 1914, p. 117.

In the previous plans of Imre Gondos, the floor plan of the synagogue was circular. Although later, in the third competition, this was changed to a square plan with an octagonal interior. He raises the dome above the square layout and creates a monumental effect with portals on three sides. The fourth side of the symmetrical structure is organically connected to the town hall (headquarters of the Jewish community) as an auxiliary wing. The blueprint, published in the Épitő Ipar-Épitö Müvészet, does not reveal some details of the plan, therefore, we have to rely on the description of S.M. (the exact identity of the writer is unknown-presumably an architect): "As witty as the arrangement of the spaces around the sanctuary is, as petty is its external design. The huge wall masses of the temple are unadorned, but the interior is beautiful and the lighting is favourable." ${ }^{49}$ Although the site plan does not show the construction of the park (garden). it is presumed that the space between the synagogue and the town hall serves this purpose. From Krisztina Boulevard a central freestanding prayer house for daily use encloses the square. Gondos designed the building of the temple on Krisztina Boulevard without a retaining wall and bridged the differences in terrain height with stairs. In terms of synagogue type, it belongs to the Byzantine church-type synagogues, of which Klein writes, "[that] highlights the fulfilment of emancipation in architectural terms: the synagogue enjoys not only the landmarking towers but domes too, embodiments of the universe" (Klein 2017, p. 307).

The four plans all follow a domed design, although there seems to be great differences between the layouts of the temple and the site plans concerning the location of the buildings and the park. Regarding the solutions, there seem to be similarities in the plans of Vilmos Magyar and József Porgesz. In both plans the synagogue was set up on a terrace with a retaining wall about 3-4 $\mathrm{m}$ high from Krisztina Boulevard. The jury criticized this plan, presented above as Figure 8, for improper design of the carriageways. The two architects have tried to resolve this issue by means of the retaining wall, however, the retaining wall detracts from the external impression of the temple. In the plan of Vilmos Magyar, the transition between the dome and the walls is created by a tambourine that lifts the dome, but not as expressively and structurally justified as in the other plans. The jury claimed: “The designer unacceptably reduced the spatial dimensions of the temple at the important parts of it. By doing so, it achieves a beneficial arrangement and unfolding of the rear façade. However, the arrangement 
appears to be disadvantaged in this way." 50 S.M. writes in his commentary article about the dome: "[the dome] is not visible from the road at all, only in the upper corner. The designer had to feel this shortcoming, too, because he composed the perspective on the horizon height (about 18-20 m), a view that nobody who is passing the road can ever capture. On the contrary, the interior effect of the temple is quite good. The side galleries are too deep, the sanctuary and the rooms around it are very narrow." ${ }^{\prime 51}$ In his plan, József Porgesz focuses more on the solution of the transition between the rectangular space of the temple and the dome. The central octagonal prayer house is connected to the synagogue with an arcade corridor. Sándor Löffler and Béla Löffler designed a tremendous front extension attached to the synagogue towards Krisztina Boulevard, and created one-storey building wings for the official premises demanded by the community. All this is designed with free staircases on both the right and the left of the façade. The contrast between the building massing and the planning is illustrated by the relationship between the elements of the building and the synagogue. The contrast is emphasized by the façade of the synagogue. "This fortunate arrangement of the masses [created by the synagogue design/the architects] ranks high above its peers and fits in the environment in the best possible way. A further advantage is that the community headquarter can be built one floor lower by removing the official areas. Thus, the overall effect is more harmonious." 52 The everyday prayer house is attached to the wall of the temple building and is placed in the courtyard between the temple and the headquarters building.

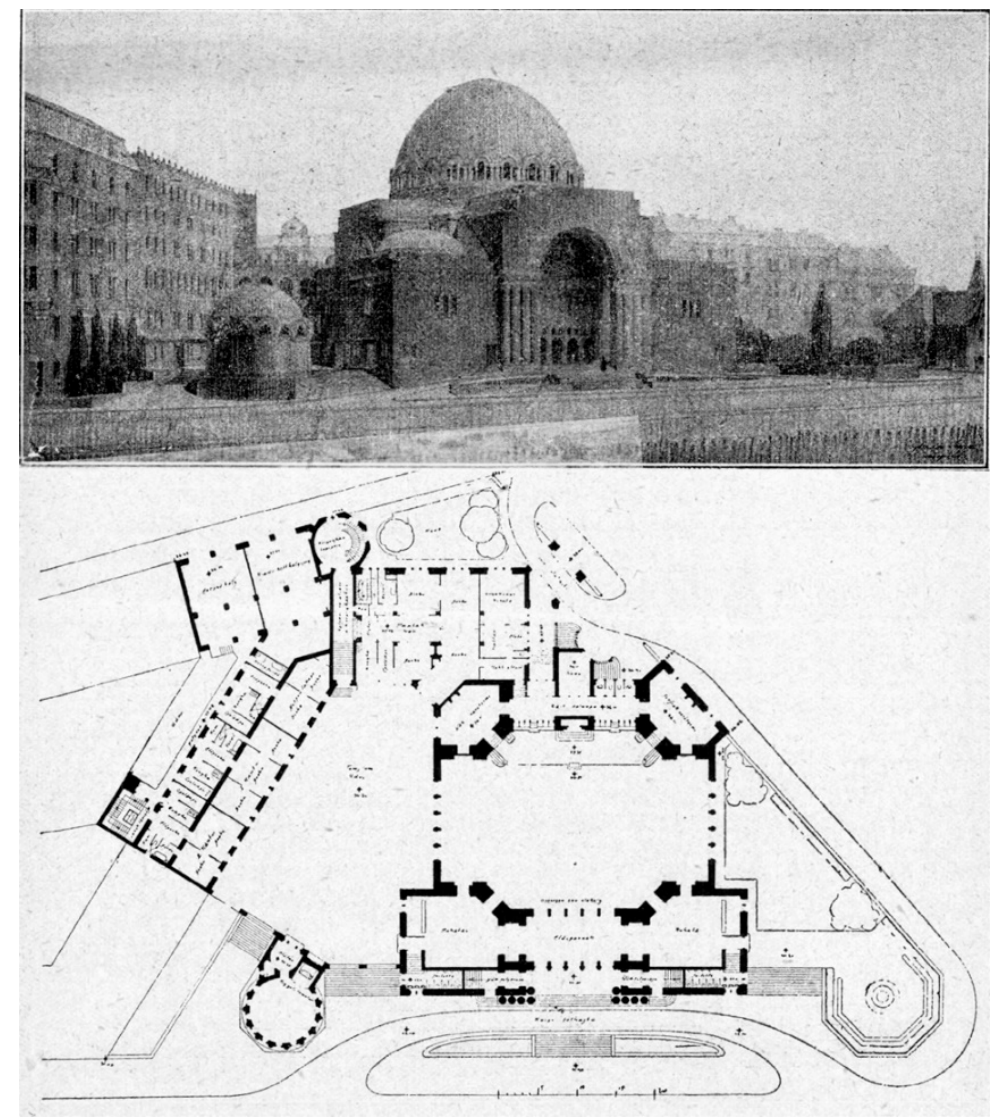

Figure 8. Perspective view and floor-plan of the Buda synagogue from the 3rd competition entry of Imre Gondos in 1914. Source: Épitő Ipar-Épitő Müvészet, 22 March 1914, p. 120.

50 Magyar, Vilmos: “A budai zsidó templom juryje." Építő Ipar-Építő Múvészet, 22 March 1914, p. 121.

51 S.M. (pseudonym): “A budai zsidótemplom tervpályázata." Épitó Ipar-Épít” Müvészet, 22 March 1914, p. 119.

52 Ibid. 
Finally, the third competition for the Buda synagogue was a partial success, as the jury selected a plan whose fundamental idea, namely the arrangement of the building elements and the appearance of the façade along Krisztina Boulevard, was well appreciated by the committee members. However, there seemed to be no detailed elaboration of any of the plans that would have made them suitable for implementation. The issue of the Buda synagogue was next discussed only in the context of the construction of the Postal Palace, about ten years later, when the capital acquired the prestigious land from the community and commissioned the design of the Postal Palace.

\section{Conclusions: Wider Context of the Buda Synagogue}

Architectural and urban design competitions in the period of the Austro-Hungarian Empire (1867-1918), especially in Budapest, laid the foundations for greater architectural diversity than was characteristic in the capital in the early 19th century. Architectural competitions were of national and international importance. According to the regulations, only Hungarian-resident architects could participate in national design competitions. This is why the invitation of an architect from Frankfurt to participate in the design competition for the Buda synagogue caused such outrage at the beginning of the 20th century. The architectural competition for the Buda synagogue was treated partly as a public investment and was a tender of national interest. This meant that it was not like investments in representations of the state such as the Parliament, the competition for which Otto Wagner and the Atelier Fellner \& Helmer participated in. Otto Wagner is an interesting figure in the Parliament's design competition, as he was a resident of Budapest at the end of the 19th century (at least he had an address in the capital). He participated in an international architectural design competition for Parliament in 1882-1883 in association with Mór Kallina and Rezső Berndt, and their design received one of the first prizes. Otto Wagner's first sacred building is the Orthodox synagogue of Rombach (Rumbach) Street in Budapest (called Pest at this time-Buda was separate. Pest and Óbuda were merged in 1872-1873 and became Budapest). In 1868, Otto Wagner won the architectural competition for a synagogue held by the Jewish community of Pest. The synagogue opened in 1872, and is one of the most exquisite Moorish-style buildings of Hungarian romantic-eclectic architecture (Sisa 1982, p. 47). Mór Kallina was the representative of Wagner in Budapest. He drew the details of the temple and led the building construction. ${ }^{53}$ Wagner's activities in Budapest are not limited to the design of the synagogue and competing for the construction of the Parliament. In 1901 he participated in an architectural competition for the headquarters of the National Bank in Budapest. Moreover, together with Mór Kallina, he built a tenement house on Váci Boulevard (now Bajcsy-Zsilinszky) in Budapest.

It is not unprecedented in the capital that a sacred building, in this case a synagogue, would be built by a non-Hungarian (not in the national sense but on the basis of their place of residence). Ludwig Förster was the architect of the Dohány Street Synagogue, opened in 1859, and the Rumbach Street synagogue is another example of this. The construction of the two synagogues was preceded by an architectural design competition.

While the above mentioned fact was not a problem in the mid-19th century, it suddenly caused great indignation in the early 20th century. This may be due to growing Hungarian national consciousness, and whether they wanted to entrust the construction of the Buda Synagogue to a Frankfurt architect.

A significant episode of the evolving Hungarian national consciousness was the domestic political crisis of 1905-1906. It was a remarkable scene in the awakening of the Hungarian nation. The Hungarian domestic political crisis of 1905-1906 unfolded after the 1905 elections, where the Freedom Party, which had been continuously governing since 1875, and had won all elections since, became a minority in parliament for the first time. The united parliamentary opposition subsequently fundamentally questioned the system of dualism (Austria-Hungary).

53 Magyar, Vilmos: “Marsnak szekerén.” Épitő Ipar-Építő Mưvészet, 4 October 1914, pp. 365-67. 
The construction of the Buda synagogue was of great importance at the national level, as it was supported by the capital and the Public Works Council, two bodies responsible for architecture and town planning in Budapest. The urban planning triangle to which the success or failure of investments in the capital could be linked were the Public Works Council, and the technical associations (architectural and industrial associations). The final decision on a draft plan was made by the Ministry of the Interior, after the capital's input was accepted. The audience of the capital city, in the words of the Austro-Hungarian Emperor at that time, referred to the committee of the jurisdiction, namely, the representative body of the local municipality. The interdependence of the city planning triangle is reflected not only in the decisions made, but in the improvement of the plans. The 'triangle' was also present in architectural competitions.

The Jewish Community in Buda was expected to obtain about $90 \%$ of the construction expenses. This might secure their position in the decision-making process regarding the land and the construction of the synagogue but, in reality, the land was already picked out by the Minister of Trade in Hungary for the third telephone exchange centre (FKT 1928, p. 96). The site became one of the urban planning priority investments in Buda. In 1923, as a result of the decision of the Minister of Trade, the Public Works Council plots on Krisztina Boulevard of were transferred to the Hungarian Royal Treasury by expropriation. They also commissioned the expropriation of two plots owned by the Jewish community. During lengthy negotiations with the Jewish community, the Public Works Council succeeded in reaching an agreement regarding town planning considerations, that the community would transfer the Krisztina Boulevard plots to the Treasury. In compensation, they had to be satisfied with the return of the old prayer house on Öntôház Street, and the ownership of the adjacent property.

The decision making process was as follows: A submission was proposed by the Public Works Council and accepted by the capital, or vice versa; the final decision was taken by the professional audience and the capital's jurisdictional committee; and then put into force by the Ministry of the Interior. A planning process which included ideas and professionals was bypassed, and there seemed to be no real separation between institutions in the case of the development of urban or architectural plans. If a proposed plan was affected by a priority investment, its investment was decided separately from the complex, urban planning issues of the area. In 1910 the Rules for architectural design contests was published in the Budapest Bulletin. In 1912 during the second competition the jury referred to paragraph 24 of the Rules.

Article 24 of the Rules for architectural design contests provides that "The prizes should be awarded for the relatively best work in full and consistent amount unless there is no work being worth for the award. That occurs by unanimous decision of the committee if the application is considered to be completely barren in terms of the design program. In this case, the committee may not take action to use either the prizes or the amounts intended for the purchase of the plans." 54 According to this, the plans of the second tender could not have been bought but the community, however, they purchased four works. The designers of these four works also participated in the third invitational competition.

According to paragraph $2^{55}$ of the Rules for architectural design contests, one member of the Hungarian Association of Engineers and Architects and another one of the Hungarian Association of Architects must be present in the committee. In case of a more important public building, the Hungarian Royal Ministry of Commerce should also delegate an architect to the jury.

The rules for architectural design contests were in force from 1910 until 1936 (the Austro-Hungarian Empire dissolved in 1918). In 1936 some sections changed to Decree No. 6.632 of the year $1936 .{ }^{56}$ According to this amendment, in the case of an invitational (private) design competition, the customer may reserve the right to appoint any of the worthy applicants for drafting the working-drawings. Even

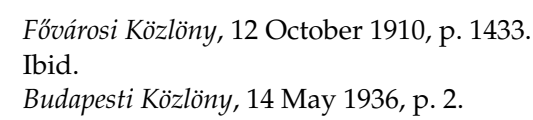


then, it was not designated in the regulations that only applicants with Hungarian residency could compete in state-sponsored architectural competitions, as had occurred in that of the Buda synagogue, which had national importance. This amendment was requested by representatives of the Budapest architectural associations from the Ministry of the Interior after the competition of 1913.

The failure of architectural designs can also be blamed on the urban context of the competition site. There seemed to be a relative ineffectiveness of the competition due to the difficult terrain conditions of the site. The area chosen for the building site of the temple has a rather steep slope, with a difference of several meters between the lower and upper levels. It was almost impossible to solve this level difference architecturally, and this was only recognised at the time of the last competition of 1914. By this time, more favourable work conditions resulted in more successful works, such as the architectural plan of the Löffler brothers. The essential concept of the architectural plan was considered appropriate ("fundamental idea": building massing and arrangement), but the jury paid less attention to the technical solution of how the architects had solved the problem of the topography.

The unrealised competitions for the construction of the Buda Synagogue had been preceded by several other successful synagogue competitions in Pest, as well as in smaller towns in Habsburg Hungary. The procedure seemed to be the same for the Szeged synagogue in 1899. The third prize winning design, which was recommended for purchase, was designed by the Komor-Jakab designer duo, who also participated in the Buda synagogue competition in 1912. Their plan for the synagogue in Szeged was finally built, with a partially revised design, in Subotica (in present day Serbia) in 1902, following the Hungarian Art Nouveau style. The plans they submitted for Buda synagogue design competition reflect the structural and architectural appearance of the Subotica synagogue. The Löffler brothers designed the Synagogue on Kazinczy Street that became the religious-cultural centre of the orthodox Jewish community in Pest. During their careers Sándor and Béla Löffler built only one synagogue building. The design of the synagogue was tendered in 1910 and handed over in 1913. Although the Löffler brothers were not successful in the second round of the competition, the community accepted their application to overturn the decision of the jury. In 1913 during the construction of the Orthodox synagogue on Kazinczy Street, the Jewish community of Cluj-Napoca asked the architects to build an Orthodox synagogue in their city as well. There is no further record regarding the Orthodox synagogue in Cluj-Napoca, only one short announcement in the newspaper. ${ }^{57}$ During the current research, no trace, record or plan was found suggesting that the design of the synagogue for the Buda design competition was intended to have been used in the design of their later buildings.

Based on the collected material, it is clear there were several reasons why the working plans were not completed, and why the Buda synagogue was not built. Firstly, in 1914 the architectural project became doubtful for financial reasons, as the capital city granted only 100,000 crowns for the works, while the estimated cost of construction was between 800,000 and 1,000,000 crowns. Furthermore, the outbreak of the First World War, the disintegration of the Austro-Hungarian Empire (1918), and the splitting up Hungary (Treaty of Trianon, 1920) all influenced the eventual outcome. After the shock of World War I and the Treaty of Trianon ${ }^{58}$ (4 June 1920), anti-Semitism intensified in Hungary. The counter-revolution turned against the Jews, and in 1920 the first restrictive law, the 'numerus clausus' policy of higher education ${ }^{59}$ (sometimes reflected as the first policy of anti-Semitism) came into force.

57 Világ, 8 July 1913, p. 17.

58 The Hungarian government terminated its union with Austria on 31 October 1918, officially dissolving the Austro-Hungarian state. The Trianon Treaty was the peace treaty between defeated Hungary (as one of the successor states of the Austro-Hungarian Empire) and the victorious Entente Powers which ended World War I. The treaty, and the accompanying dissolution of the Austro-Hungarian Empire, defined Hungary's new borders, and created many small multinational states in place of the empire.

59 The aim of the law was to restrict the number of Jews to $6 \%$ of the universities' population, which was their proportion in Hungary at that time. 
Although the economic situation had improved by the end of the 1930s, so-called Jewish laws increasingly deprived domestic Jews of their rights. From 1938, a total of four Jewish laws were enacterd by the Hungarian Parliament, and they became increasingly stringent.

In 1936, despite increasing anti-Semitism and the preparation of the anti-Jewish laws, the Lágymányos Synagogue was built at 37 Bocskai Street. ${ }^{60}$ It was the only completed part of a planned building complex. The modern-style synagogue reflected the traditions of Oriental-Romantic synagogue architecture and the Bauhaus. The tall, square-shaped building's clean, nearly square-shaped, red-framed, red windows resembled the Old Testament, and the staircase's glass walls were adorned with the Stars of David. The building was designed by Ede Novák and István Hámori (Hamburger). ${ }^{61}$

The study has presented the different layers of perception of synagogue buildings and different layers of discernment of the Buda synagogue and its architectural journey. The layers of perception included the architectural and urban architecture substrata, the objective expectations of the synagogue competition, and the subjective opinion of the jury, and the events that followed and shaped the competition. It reflects the contradictions between the official expectations of the architectural competition and the implemented standards, and the indignation of the architects and architectural associations of the time.

Despite the background and the competitions, we have to accept the fact that even in the most ideal circumstances, the synagogue would never be built on the site between Krisztina Boulevard, Csaba Street, Vérmező Street and Várfok Street in District I of Buda. The Jewish Community became an object rather than the subject of the decision-making process.

\section{Materials and Methods}

The research is based on primary sources and the author's analyses, as in the past 100 years no professional studies have dealt with and analysed the different layers of the three related architectural competitions for the Buda synagogue. The details of the planning history of the architectural competition for the Buda synagogue came together based on the study of articles in contemporary (1910s and 1920s) weekly publications and specialist journals, as well as the official regulations.

In addition to the official reports of the architectural competitions, it was important to understand the opinions of contemporaries and of the architects who dealt with the subject and who participated in the architectural contests. The study strives for objectivity throughout the narrative, but also conveys the social atmosphere evoked by the events of these three years.

Primary sources were contemporary newspapers (Pest Diary-Pesti Napló, Pest Newspaper-Pest Hírlap, The Newspaper-Az Újság, Budapest Newspaper-Budapesti Hírlap, World-Világ, Hungary-Magyarország), thematic architectural magazines (Construction-Construction Art-Építő Ipar-Építő Múvészet, Construction Art—Design Contests—Építő Múvészet—Tervpályázatok) and official bulletins (Bulletin of the Buda Jewish Community-A Budai Izraelita Hitközség Értesítője, Bulletin of the Capital—Fővárosi Közlöny, Official reports of the Municipal Public Works Council—A Fővárosi Közmunkák Tanácsának hivatalos jelentései).

The architectural and urban design analysis aims to ascertain the quality of the plans and the architectural and urban design significance of the architectural contest and place it in an urban context in the capital.

The analysis seeks to point out that, despite the unsuccessful tenders, architecturally valuable synagogue designs were made by the leading architects of the era.

The synagogue designs and the situation plans of the Buda synagogue and its surrounding, especially the synagogue itself, came into a global context through the typology of Central European synagogues.

\footnotetext{
60 "Az új budai zsinagóga felavatása." Pesti Napló, 15 September 1936, p. 13.

61 “Az új lágymányosi templom." Tér és Forma, 1936, vol. 12, pp. 353-56.
} 
The conclusions were summarized and developed by the floor plans and perspectives were published in the thematic papers.

Funding: This research received no external funding.

Acknowledgments: The study was made within the framework of Akcija Vlade APV "Pravo na prvu Šansu", project: "Microurbanism-Interaction between Architecture and Urban Structure in Central Europe (1867-1918)". Permission to use Figure 1 is granted according to the Creative-Commons' license "Attribution-ShareAlike" 2.0 (CC BY-SA 2.0). Permission to publish the rest of the figures is according to the 35. § (1). Hungarian Law of Copyright (1999. évi LXXVI. törvény a szerzői jogról).

Conflicts of Interest: The author declares no conflict of interest.

\section{References}

FKT. 1928. Fö́városi Közmunkák Tanácsának Hivatalos Jelentése [1923-1927]. Budapest: Hellas Irodalmi és Nyomdai Részvénytársaság.

Kann, Robert A. 1977. A History of the Habsburg Empire, 1526-1918. Los Angeles: University of California Press.

Klein, Rudolf. 2013. Lajta építészete és a zsidó szellem. In Az Épitészet Mesterei-Lajta Béla, 1st ed. Edited by János Gerle. Budapest: Holnap kiadó, pp. 29-44.

Klein, Rudolf. 2017. Zsinagógák Magyarországon 1782-1918. Budapest: Terc.

Lajta Archive. 2010. A Budai Zsinagóga Pályaterve, 1912. (I. dij). Available online: http://lajtaarchiv.hu/muvek/abudai-zsinagoga-palyaterve-1912-xii-krisztina-korut-moszkva-ter/ (accessed on 11 August 2019).

Moravánszky, Ákos. 1998. Competing Visions: Aesthetic Invention and Social Imagination in Central European Architecture, 1867-1918. Cambridge: MIT Press.

Sisa, József. 1982. A Rumbach utcai zsinagóga, Otto Wagner ifjúkori alkotása. Ars Hungarica 1: 43-49.

Újvári, Péter, ed. 1929. Magyar Zsidó Lexikon. p. 149. Available online: http://www.elib.hu/04000/04093/html/ (accessed on 12 September 2019).

(C) 2019 by the author. Licensee MDPI, Basel, Switzerland. This article is an open access article distributed under the terms and conditions of the Creative Commons Attribution (CC BY) license (http://creativecommons.org/licenses/by/4.0/). 